\title{
High density lipoprotein promoting proliferation and migration of type II alveolar epithelial cells during inflammation state
}

\author{
Zhongji Yu ${ }^{1,2}$, Jingru Jin' ${ }^{2}$ Yuhui Wang ${ }^{3}$ and Jian Sun ${ }^{1 *}$ (D)
}

\begin{abstract}
Background: To investigate the effect and mechanism of high density lipoprotein (HDL) on type II alveolar epithelial cells during inflammation state.

Methods: The original generation of type II alveolar epithelial cells were separated in rats and treated with PBS/LPS/HDL/HDL + LPS. To observe the proliferation and migration of type II alveolar epithelial cells with bromodeoxyuridine(BrdU) assay, transwell assay and wound healing experiments. In addition, western blot detected the expression of TP-binding cassette transporter A1 (ABCA1), cystic fibrosis transmembrane conductance regulator (CFTR) and the phosphorylation of AKT/extracellular signal-regulated kinase(ERK)/ mitogen-activated protein kinase(MAPK). Enzyme-linked immunosorbent assay (ELISA) tested the secretion of tumor necrosis factor a(TNF-a)/interleukin 1a(IL-1a)/IL-6.

Results: HDL promoted the proliferation ( $\uparrow 17 \%, p<0.001$ HDL+ LPS vs. LPS) and migration (wounding healing: $\uparrow 93 \%$, $p<0.001 \mathrm{HDL}+$ LPS vs. LPS; transwell migration: $\uparrow 154 \%, p<0.001 \mathrm{HDL}+$ LPS vs. LPS) of type II alveolar epithelial cells. Furthermore, $\mathrm{HDL}$ increased the phosphorylation of MAPK, but not AKT/ERK. And HDL decreased the secretion of TNF-a ( $\downarrow 46 \%, p<0.01 \mathrm{HDL}+$ LPS vs. LPS) and IL-1a $(\downarrow 45 \%, p<0.001 \mathrm{HDL}+$ LPS vs. LPS), but not IL-6. In addition, $\mathrm{HDL}$ up-regulated the expression of $\mathrm{ABCAl}(\uparrow 99 \%, p<0.001 \mathrm{HDL}$ vs. CON) and down-regulated the expression of CFTR $(\downarrow 25 \%, p<0.05 \mathrm{HDL}$ vs. CON) in type II alveolar epithelial cells.

Conclusions: $\mathrm{HDL}$ increases the phosphorylation of MAPK, which promotes the proliferation and migration of type II alveolar epithelial cells. And it decreased the secretion of TNF-a/LL-1a and the expression of CFTR. All these suggest that HDL plays an important role in anti-inflammatory effect in inflammation state of lung.
\end{abstract}

Keywords: High density lipoprotein, Type II Alveolar epithelial cells, Inflammation, Proliferation, Migration

\section{Background}

Pulmonary alveoli, composed of type I and type II alveolar epithelial cells, are the sites for gas exchange between the blood and the atmosphere. Type II alveolar epithelial cells take charge of the production and turnover of pulmonary surfactant, the protein-lipid mixture that serves to lessen the surface tension in the alveolus permitting for lung ventilation smoothly [1]. Type I alveolar epithelial

\footnotetext{
*Correspondence: cdsfysj@163.com

'The Fourth Affiliated Hospital of Nanchang University, Nanchang 330003,

China

Full list of author information is available at the end of the article
}

cells do not proliferate, when injured they are replaced by type II alveolar epithelial cells that transdifferentiate into type I alveolar epithelial cells.

HDL mediate reverse cholesterol transport out of cells. Many studies have shown that HDL has atheroprotective functions [2]. In addition, the role of anti-inflammation, anti-oxidation and anti-apoptotic, were also tested [3]. These functions are increasingly being recognized to be active in the pulmonary system [4]. These indicated that HDL and apoA-I have protective effects in pathophysiological states. 
Some studies shown that HDL inhibit the secretion of inflammation cytokines and against endotoxin [5]. Some studies tested that HDL inhibit cytokine-induced expression of adhesion molecules [6]. Some studies revealed that HDL plays a role of anti-inflammation in lung as it is the major source of vitamin $\mathrm{E}$ for type II pneumocytes and alveolar surfactant is supplemented with vitamin $\mathrm{E}$ during its assembly in type II pneumocytes [7].

To better understand the effect of HDL on type II alveolar epithelial cells during inflammation state, this study observed the proliferation and migration of type II alveolar epithelial cells stimulated by lipopolysaccharide (LPS) and HDL. We also examined the signaling pathways of proliferation and migration, including PI3K/ Akt, extracellular signal-regulated kinase (Erk1/2) and mitogen-activated protein kinase (p38MAPK).

\section{Methods}

\section{Ethics statement}

Healthy subjects were recruited in our study. Each participant provided written informed consent. The study protocol was approved by the Institutional Review Board of the Fourth Affiliated Hospital of Nanchang University, China.

\section{Cell culture and material}

Type II alveolar epithelial cells were isolated as described previously [8] and cultured in Dulbecco's modified Eagle's medium (DMEM; GIBCO, UK) supplemented with 10\% fetal bovine serum. Cells were grown on $0.1 \%(w / v)$ gelatin-coated culture ware and then cultured in a humidified incubator at $37{ }^{\circ} \mathrm{C}$ with an atmosphere of $5 \% \mathrm{CO}_{2}$.

Antibodies for western blotting against ABCA1 and bactin were from Abcam, USA. Antibody against PhosphoAkt, phospho-ERK1/2 and phospho-p38 MAPK were from Cell Signaling Technology, USA. Anti-ERK1/2 antibody, anti-p38MAPK antibody, anti-Akt antibody were purchased from Santa Cruz Biotechnology (Santa Cruz, CA). HRP-goat-anti-rabbit IgG and HRP-goat-anti-mouse IgG were purchased from MBL (Nagoya, Japan)BrdU proliferation ELISA kit was from Roche Applied Science, Germany.

\section{Isolation of lipoproteins}

Plasma was obtained by centrifugation from peripheral blood of fresh fasting healthy subjects. This part was approved by the local ethics committee. HDL ( $\mathrm{d}=1.063-$ $1.210 \mathrm{~g} / \mathrm{ml}$ ) was isolated by sequential ultracentrifugation as described elsewhere [9]. Resulting preparations of lipoproteins were dialyzed against of phosphate-buffered saline (PBS) $(\mathrm{pH}=7.4)$ containing $1 \mathrm{mM}$ EDTA and $100 \mu \mathrm{M}$ diethylenetriamine pentaacetic acid (DTPA) (Sigma, USA), sterilized with $0.22-\mu \mathrm{m}$ filter, stored away from light at $4{ }^{\circ} \mathrm{C}$ and used within 1 months. HDL concentration was determined by immunoturbidimetrical detection of apolipoprotein A-I (Roche Diagnostic).

\section{BrdU proliferation assay}

Type II alveolar epithelial cells $\left(5 \times 10^{3}\right.$ cells/well $)$ were seeded in 96-well plates with Dulbecco's Modified Eagle's Medium and 10\% fetal bovine serum and cultured overnight. And then, Type II alveolar epithelial cells were treated with HDL (100 mg/ml apoA-I concentration), LPS $(1 \mu \mathrm{g} / \mathrm{ml}), \mathrm{LPS}+\mathrm{HDL}$ or Control for $48 \mathrm{~h}$. The cells were labeled with $20 \mathrm{ml} /$ well of BrdU labeling solution as described previously [10], and then incubated with $200 \mathrm{ml} /$ well of FixDenat. After incubated with $100 \mathrm{ml} /$ well of Anti-BrdU-POD working solution for $90 \mathrm{~min}$ and washed 3 times, substrate solution (TMB) was added and the absorbance of each well was read at $450 \mathrm{~nm}$ with an ELISA plate reader (model 550, BioRad, USA).

\section{Wound healing}

Type II alveolar epithelial cells were plated with Dulbecco's Modified Eagle's Medium and 10\% fetal bovine serum in 24-well plate $\left(5 \times 10^{5} / \mathrm{ml}\right.$ cells/ well). And then, type II alveolar epithelial cells were serum deprived and scratched, treated with HDL (100 mg/ml apoA-I concentration), LPS $(1 \mu \mathrm{g} / \mathrm{ml}), \mathrm{LPS}+\mathrm{HDL}$ or Control. $18 \mathrm{~h}$ later Type II alveolar epithelial cells were fixed with methanol, stained with hematoxylin-eosin stain, and viewed under an inverted microscope (Nikon, Japan).

\section{Transwell experiments}

Quantitative migration assays with type II alveolar epithelial cells were performed using a modified Boyden chamber (Minicell, Millipore, USA) as described previously [11]. The Transwell insert was placed back to the 24-well plate and the lower chamber was filled with $0.6 \mathrm{ml}$ of Dulbecco's Modified Eagle's Medium and 5\% bovine serum. Type II alveolar epithelial cells (5000 cells/well) in Dulbecco's Modified Eagle's Medium were plated into the upper chamber. HDL $(100 \mathrm{mg} / \mathrm{ml}$ apoA-I concentration), LPS $(1 \mu \mathrm{g} / \mathrm{ml})$, LPS + HDL or Control was individually added to the upper chamber. After $8 \mathrm{~h}$ incubation, all nonmigrated cells were removed from the upper face with a cotton swab, and migrated cells were fixed and stained with hematoxylin-eosin stain. Cell migration was quantified by counting the number of stained cells per in 10 random fields photographed for each chamber.

\section{Type II alveolar epithelial cells -ECM adhesion assay}

Type II alveolar epithelial cells pretreated with HDL or LPS were incubated in wells coated with Matrigel Membrane Matrix [12]. Wells were coated with $20 \mathrm{ml}$ of $0.1 \mathrm{mg} / \mathrm{ml}$ Matrigel Membrane Matrix (Vigorous Biotechnology Beijing Co., China) in PBS at room 
temperature and air dry in 96-well plates. The type II alveolar epithelial cells were serum deprived and pretreated with N-HDL or LPS for $24 \mathrm{~h}$ before plating into each well. The plates were blocked with $20 \mathrm{ml} 2 \%$ BSA at $37 \mathrm{uC}$ for $1 \mathrm{~h}$, and then washed with PBS. The pretreated type II alveolar epithelial cells in DMEM with $0.1 \%$ BSA were plated in each well at a density of $8^{*} 10^{4}$ cells/well for $1 \mathrm{~h}$ at $37 \mathrm{uC}$. Thereafter, non-adherent cells were removed by washing with PBS 3 times and $40 \mathrm{mg} /$ well of MTT was added for $4 \mathrm{~h}$ at $37 \mathrm{uC}$. After discarding MTT and adding $200 \mathrm{ml}$ DMSO, and measuring the absorption at $570 \mathrm{~nm}$ (model 550, BioRad, USA).

\section{ELISA analysis of TNF-a、IL-1a and IL-6}

Cells were seeded onto six-well plates and then treated with HDL, LPS in serum-free DMEM for $6 \mathrm{~h}$. Supernatants were collected, centrifuged (10 min, $1500 \mathrm{~g})$ at room temperature and stored at $-80{ }^{\circ} \mathrm{C}$ until use. Concentrations of TNF-a, IL-1a and IL- 6 were determined from cell culture supernatants.

\section{Western blot analysis}

After treatments, cells were washed with PBS and lysed in RIPA buffer. Cell debris was removed by centrifugation $(12,000 \mathrm{~g}$ for $15 \mathrm{~min})$, and protein concentrations were quantified using the Coomassie brilliant blue method. Equal amounts of total protein were separated by SDSPAGE and then blotted onto nitrocellulose membranes. The membranes were blocked in 5\% non-fat dry milk for $1 \mathrm{~h}$ and then incubated with primary antibodies for $4 \mathrm{~h}$ followed by the appropriate HRP-conjugated secondary antibody for $2 \mathrm{~h}$ at room temperature.

\section{Statistical analysis}

All experiments were repeated at least three times. Analysis of variance was performed using GraphPad Prism (San Diego, CA, USA). One-way ANOVA was conducted to compare overall differences among multiple groups.
Post-hoc comparisons were performed using Tukey's or Bonferroni's test. A $p$-value of $<0.05$ was considered statistically significant. Data are expressed as the mean \pm SD unless stated otherwise.

\section{Results}

HDL stimulates Type II alveolar epithelial cells proliferation

BrdU tested the proliferation of type II alveolar epithelial cells induced by HDL. The incubation of HDL $(100 \mathrm{mg} /$ $\mathrm{ml}$ apoA-I) led to $51 \%$ increase in relative cell number compared to control and 35\% increase in relative cell number compared to LPS. The incubation of HDL+ LPS led to $17 \%$ increase in relative cell number compared to LPS but $13 \%$ decrease in relative cell number compared to HDL. (Figure 1a, $n=3, p<0.001$ comparing HDL vs. con; $p<0.001$ comparing HDL+ LPS vs. LPS).

\section{HDL stimulates Type II alveolar epithelial cells migration}

HDL increased the migration of type II alveolar epithelial cells in the wound area by $76 \%$ vs. control and by $133 \%$ vs. LPS; HDL+ LPS also increased type II alveolar epithelial cells migration by $93 \%$.vs. LPS. However, HDL+ LPS decrease type II alveolar epithelial cells migration to $17 \%$ compare to HDL. (Figure $2 \mathrm{~b}$ and $\mathrm{d}, n=3 ; p<0.001 \mathrm{com}$ paring HDL vs. control, $p<0.001$ for HDL+ LPS vs. LPS). In addition, to determine the effect of HDL to the migration of type II alveolar epithelial cells incubated with control media, LPS, HDL, or HDL+ LPS for $8 \mathrm{~h}$. Transwell migration assay showed that HDL promoted the migration of type II alveolar epithelial cells, while LPS inhibited the migration. HDL increased the migration cell by $116 \%$ vs. control and by $208 \%$ vs. LPS; HDL+ LPS increased migration by $154 \%$.vs. LPS. However, HDL+ LPS decreased migration to $18 \%$ compare to HDL. (Figure $2 \mathrm{a}$ and c, $n=3$; $p<0.001$ comparing HDL vs. control, $p<0.001$ for HDL+ LPS vs. LPS or HDL).
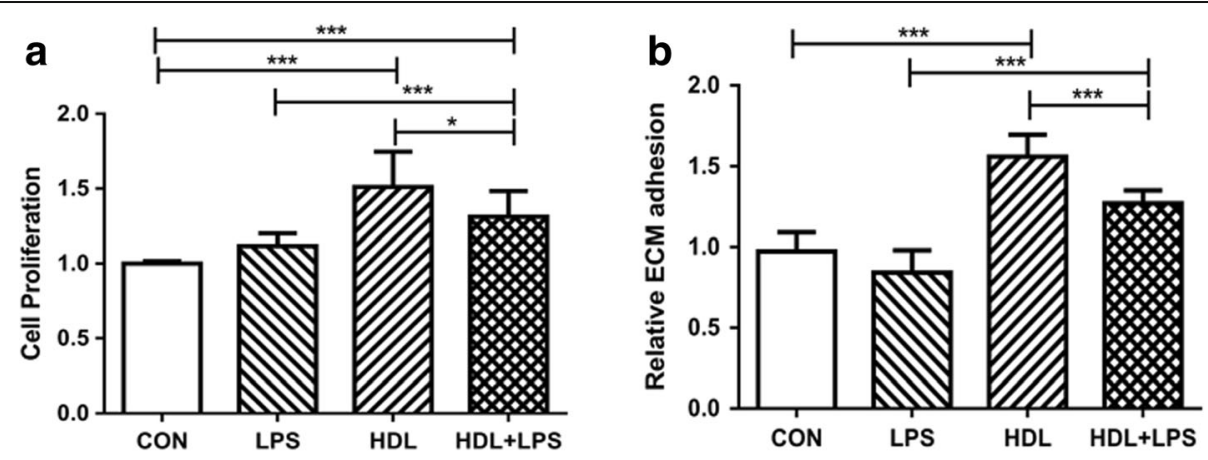

Fig. $1 \mathrm{HDL}$ Promoting Proliferation and adhesion to ECM of Type II Alveolar Epithelial Cell. a Type II Alveolar Epithelial were treated with control, $\mathrm{HDL}, \mathrm{LPS}$ and HDL + LPS, and cell proliferation was measured using BrdU assay $(n=3)$. b Type II Alveolar Epithelial were treated with control, HDL, LPS and HDL + LPS for $24 \mathrm{~h}$, and relative cell adhesion to ECM was determined after 1 hour incubation $(n=3) .\left(^{*} P<0.05\right.$; $\left.{ }^{* * *} P<0.001\right)$ 

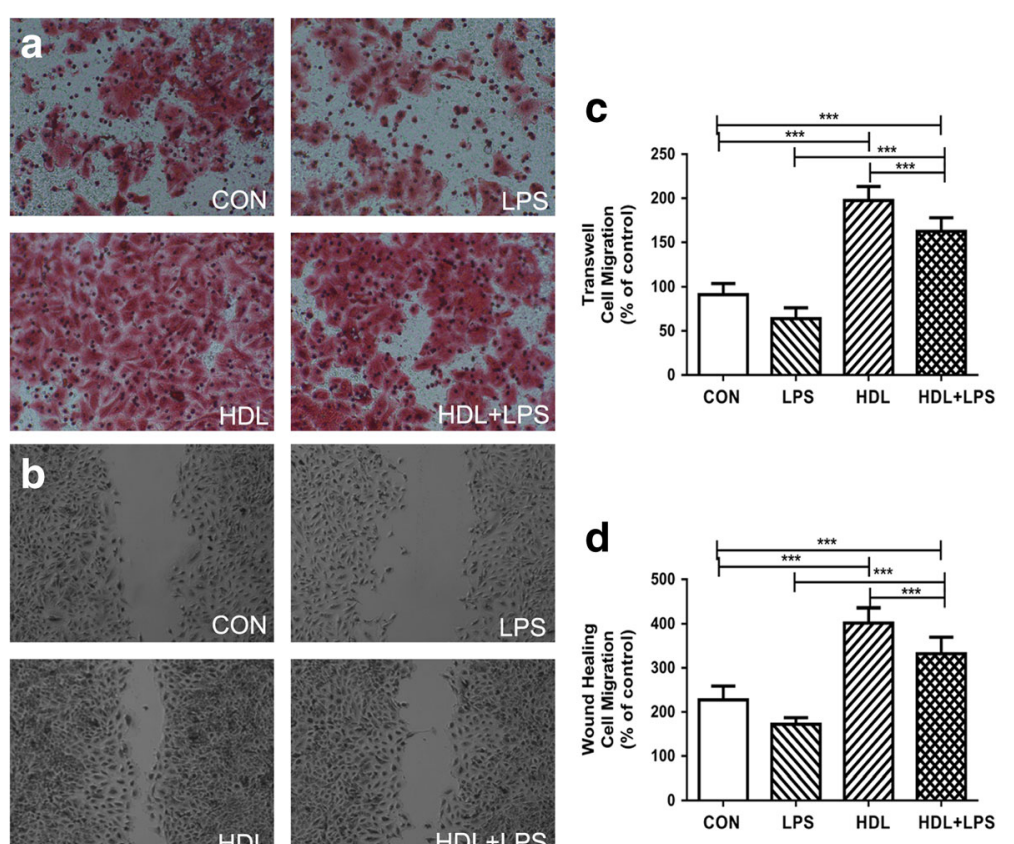

Fig. 2 HDL Promoting Migration of Type II Alveolar Epithelial Cell. a Type II Alveolar Epithelial were treated with control, HDL, LPS and $\mathrm{HDL}+\mathrm{LPS}$, and transwell migration was evaluated after $8 \mathrm{~h}$. c Quantification values are expressed as the mean $\pm \mathrm{SD}(n=3)$. $\mathbf{b}$ Type II Alveolar Epithelial were treated with control, HDL, LPS and HDL + LPS, and migration into the wound was photographed. d Quantification values are expressed as the mean $\pm \mathrm{SD}(n=3)$. (**P $<0.001)$

HDL promotes type II alveolar epithelial cells adhesion to ECM

We observed significantly increased adhesion of type II alveolar epithelial cells to ECM after HDL pretreatment compared to control. In addition, HDL+ LPS statistically increased adhesion vs. LPS. (Figure $1 \mathrm{~b}, n=3$ ).

\section{HDL up-regulates the expression of ABCA1 in type II alveolar epithelial cells}

The apoA-I/ABCA1 pathway maintains normal lipid homeostasis in the lung [1]. Many studies have demonstrated a protective role for an apoA-I/ABCA1 pathway in the pathogenesis of lung disease [4]. The effect of epithelial migration and proliferation play an important role in the damage repairing of lung. To determine whether ABCA1, an important cholesterol transporter, was involved in functional of HDL, we examined the levels of cellular ABCA1 by Western blot. HDL led to 99\% increased ABCA1 expression in type II alveolar epithelial cells compared to control. And it showed lower protein expression of ABCA1 after treated with LPS (Fig. 3 a and b).

\section{HDL activates signaling pathways}

Akt, ERK and p38MAPK phosphorylation had been demonstrated to play a role in the signal transduction leading to endothelial cells proliferation and migration $[13,14]$. Whether the similar signal pathways were seen in type II alveolar epithelial cells is unknown. Here cell signaling pathways in type II alveolar epithelial cells was performed to assess activation levels of Akt, ERK and p38MAPK pathways with HDL treatment as shown in Fig. 4. In this study, we test that HDL led to significant increase of AKT, ERK and p38MAPK phosphorylation

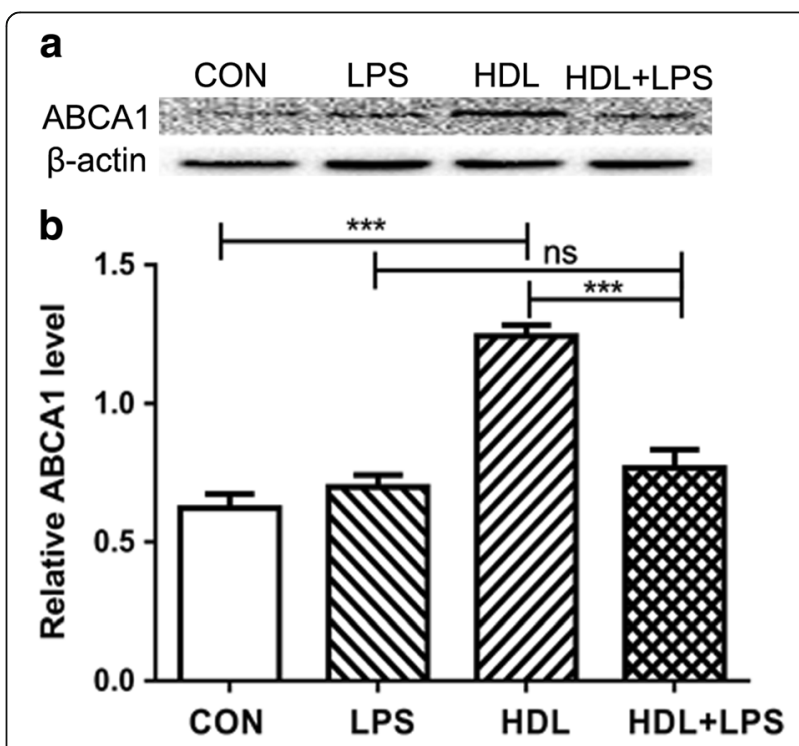

Fig. $3 \mathrm{HDL}$ Up-regulates the Expression of ABCA1. a Type II Alveolar Epithelial were treated with control, HDL, LPS and HDL + LPS, and ABCA1 expression was shown (b) $(n=3)$ (*** $<0.001$; ns, not significant) 


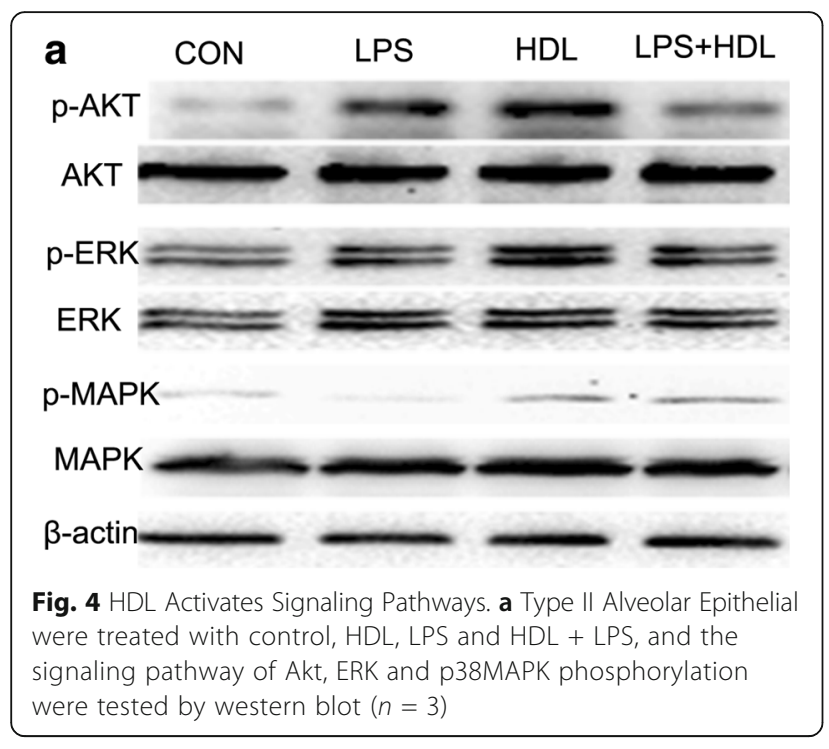

in type II alveolar epithelial cells compared to control. In addition, HDL+ LPS increased the phosphorylation of p38MAPK vs. LPS. While the significant change didn't seen in the phosphorylation of ERK and AKT.

\section{HDL inhibites secretion of TNF-a、IL-1a and IL-6 and the expression of CFTR}

The secretion of proinflammatory factors play crucial role on development of inflammation of lung. Many studies had revealed that the proinflammatory factory like TNF-a, IL-1a and IL-6 have an effect on the lung disease. Our study founding that HDL significantly inhibited secretion of TNF-a, IL-1a but not IL-6. As shown in Fig. 5, LPS highly increased the secretion of TNF-a and IL-1a. HDL+ LPS decreased the secretion of TNF-a by $46 \%$ and IL-1a by $45 \%$ vs. LPS, but not exhibit statistical significance compare with HDL. In addition, there is no difference in the secretion of IL-6 among LPS group, HDL group and HDL+ LPS group seen in Fig. 5a-c.

Furthermore, HDL treatment led to $25 \%$ decreased CFTR expression in type II alveolar epithelial cells compared to control treatment. And it showed higher protein expression of CFTR after treated with LPS seen in Fig. 6.

\section{Discussion}

HDL play key roles in reverse cholesterol transport out of cells. Furthermore, HDL has anti-oxidative, antiinflammatory, anti-apoptotic, and additional protective functions. These patterns are increasingly being identified to be active in the pulmonary system. HDL play an important protective role in normal lung health and in a variety of disease states as it modulates normal lung development and lung lipid homeostasis [4].

Ingrid et al. put forward that HDL is the primary source of vitamin E for type II pneumocytes and alveolar surfactant is supplemented with vitamin E during its assembly in type II pneumocytes [7]. Sharifov et al. test that apolipoprotein A-I (apoA- I, the major protein of) directly bind and neutralize LPS, which is derived from the cell walls of gram-negative bacteria, as well as lipoteichoic acid (a cell wall component of gram-positive bacteria) [15]. Wurfel et al. propose that apoA-I can also associate with the lipopolysaccharide-binding protein,
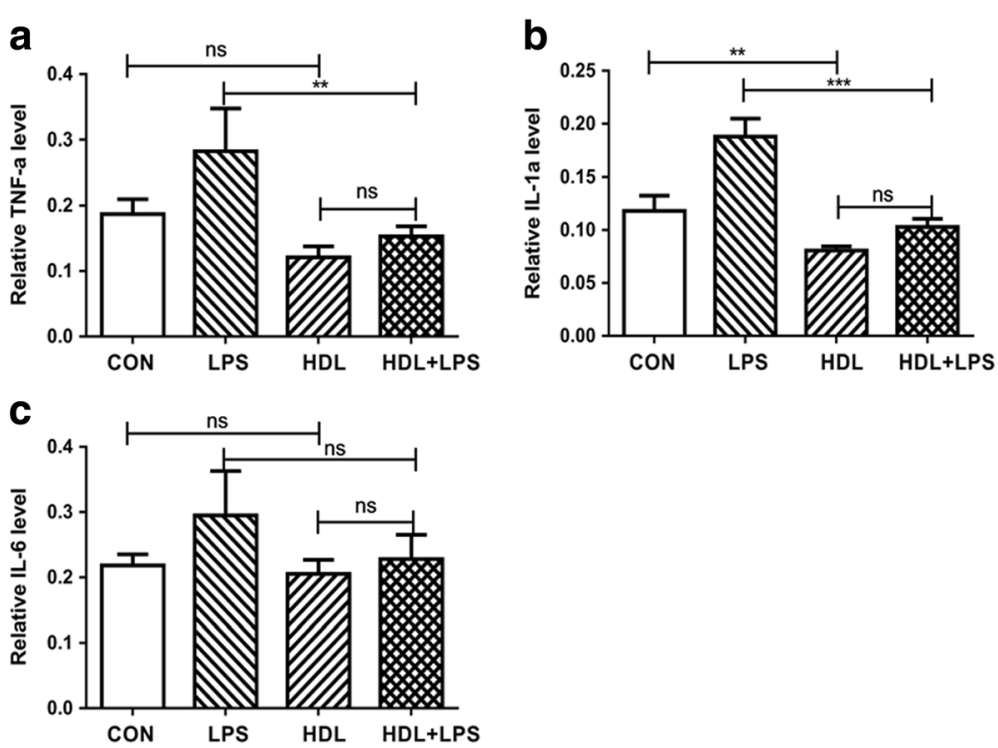

Fig. 5 HDL Inhibits Secretion of TNF-a、IL-1a. Type II Alveolar Epithelial were treated with control, HDL, LPS and HDL + LPS. And TNF-a (a), IL-1a (b) and IL-6 (c) in media were measured by ELISA $(n=3)\left({ }^{* *} P<0.01\right.$; ${ }^{* *} P<0.001$; ns, not significant) 


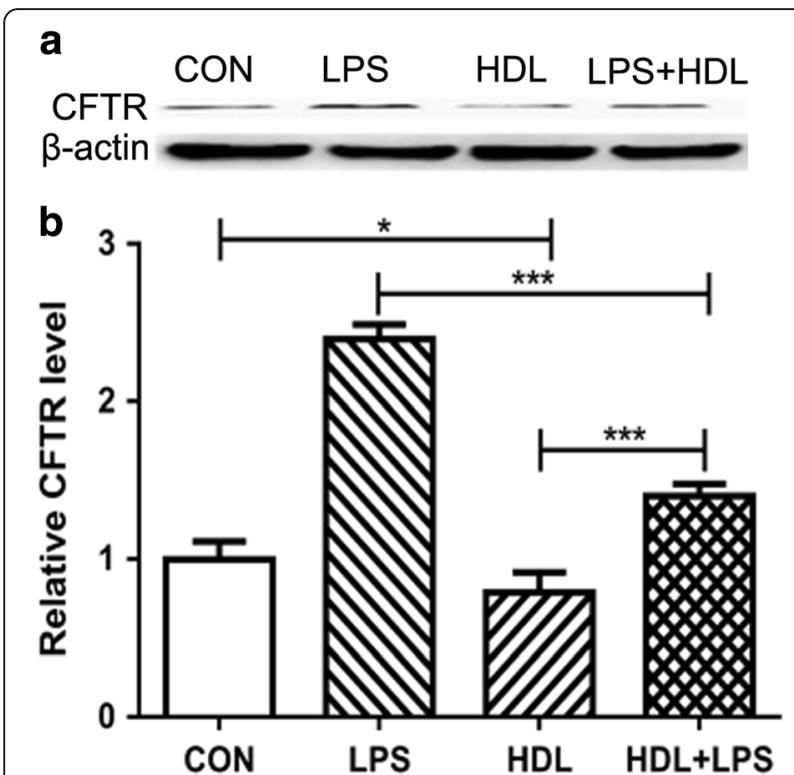

Fig. $6 \mathrm{HDL}$ Inhibits CFTR expression. a Alveolar Epithelial were treated with control, HDL, LPS and HDL + LPS, and CFTR expression was shown $(\mathbf{b})(n=3)\left({ }^{*} P<0.05 ;{ }^{*} P<0.01 ;{ }^{* *} P<0.001\right)$

which binds and neutralizes LPS [16]. In this study, we test that HDL stimulate type II alveolar epithelial cells proliferation and migration. As we known, alveolar epithelial cells (AEC) regulates gas exchange across the alveolo-capillary membrane and play a key role in keeping alveoli relatively 'dry' as it continuously carryout liquid from the alveolar space through the cationic and water channels located at the AEC apical surface [17]. Type II alveolar epithelial cells take charge of the production and turnover of pulmonary surfactant, the protein-lipid mixture that serves to lessen the surface tension in the alveolus permitting for lung ventilation smoothly ${ }^{1}$. Type II alveolar epithelial cells are responsible for epithelium reparation upon injury and ion transport [18]. Type II alveolar epithelial cells contribute also to lung defense by secreting antimicrobial products such as complement, lysozyme, and surfactant proteins. So the promotion of proliferation and migration of type II alveolar epithelial cells benefit the defense of lung disease.

As we known, ABCA1 is one of the major proteins involved in receptor-mediated cholesterol efflux. ABCA1 transporter is expressed by type I and type II alveolar epithelial cells, alveolar macrophages, pulmonary vascular endothelial cells (PVECs), and airway smooth muscle cells in the adult lung [19-21]. McNeish et al. [22] and Bates et al. [23] test that ABCA1 play an important role in maintaining normal lipid homeostasis in the lung as they finding alveolar macrophages and type II alveolar epithelial cells from Abca1-deficient mice are enriched with cholesterol. Bortnick et al. propose that ABCA1 expression in type II cells increases the removal of cholesterol mass and decreases basal rates of surfactant secretion [24]. In this study, we demonstrate that HDL treatment led to highly increased ABCA1 expression in type II alveolar epithelial cells. So we think that maybe HDL stimulate type II alveolar epithelial cells proliferation and migration by increasing the expression of $\mathrm{ABCA} 1$ in type II alveolar epithelial cells.

HDL has multiple endothelial actions which afford cardiovascular protection, among which, EC proliferation and migration may play a crucial role in vascular self-repair [25]. And many studies have test that HDL exerted its protective effects through stimulating several signaling pathways, including PI3K/Akt, Erk1/2 and p38MAPK activation in endothelial cell. As we known the effect of epithelial migration and proliferation play an important role in the damage repairing of lung. Here we experiment that the signaling pathways of PI3K/Akt, Erk1/2 and p38MAPK activation in epithelial cell. In this study, HDL treatment led to significant increasement phosphorylation of AKT, ERK and p38MAPK in type II alveolar epithelial cells vs control treatment. While during the inflammation state by LPS, HDL increased the phosphorylation of p38MAPK but not ERK and PI3K/ Akt. All this indicate that the signaling pathways of PI3K/Akt, Erk1/2 and p38MAPK activation play an important role in normal lung health. And the signaling pathways of $\mathrm{p} 38 \mathrm{MAPK}$ activation has a protective effect on inflammation of lung.

The secretion of proinflammatory factor is a crucial part in inflammation of lung. Kwon et al. and Sharifov et al. test that apoA-I avoided rodents from suffering neutrophilic airway inflammation and ALI in models of LPS- or LTA-mediated systemic inflammation. Xiao et al. experiment that administration of human HDL to mice has also attenuated LPS-induced acute lung injury (ALI) [26]. Sharifov et al. study that treatment of LPSstimulated human blood with the L-4F apoA-I mimetic peptide suppressed endotoxin activity and IL-6 secretion [15]. Alveolar epithelial cells may promote to inflammatory events in ALI/acute respiratory distress sydrome (ARDS) and are an important source of cytokines (eg. TNF-a, IL-1b, IL-6) and chemokines (eg. monocyte chemotactic protein MCP-1, IL8) under inflammatory Conditions [27-29]. In this experiment, LPS highly increased the secretion of TNF-a and IL-1a but not IL- 6 . And HDL inhibit the releasing of TNF-a and IL-1a during LPS-stimulated inflammation state. CFTR, a cAMP dependent and ATP-gated chloride channel that regulates epithelial surface fluid secretion in respiratory, link to chronic lung inflammation [30]. This study revealed that HDL decrease the expression of CFTR in type II alveolar epithelial cells. 


\section{Conclusion}

HDL elevates the expression of ABCA1 and activates the signaling pathways of $\mathrm{p} 38 \mathrm{MAPK}$ which promotes epithelial migration and proliferation during LPS-stimulated inflammation state. In addition, HDL decreases the secretion of TNF-a and IL-1a. In summary, our findings favor the notion that HDL plays a protective role in inflammation of lung, at least in part, as a result of promoting migration and proliferation of type II alveolar epithelial cells and inhibiting the releasing of proinflammatory factory like TNF-a and IL-1a.

\section{Abbreviations}

ABCA1: ATP-binding cassette transporter A1; CFTR: Cystic fibrosis transmembrane conductance regulator; ERK: Extracellular signal-regulated kinase; HDL: High density lipoprotein;; IL: Interleukin; LPS: Lipopolysaccharide; MAPK: Mitogen-activated protein kinase; TNF: Tumor necrosis factor

\section{Acknowledgments}

Not applicable.

\section{Funding}

This work was supported by Grants GJJ13194 from the Foundation of Jiangxi, China.

\section{Availability of data and materials}

All data generated or analyzed during the current study are available from the corresponding author on reasonable request.

\section{Authors' contributions}

$Z Y$ and JS designed the experiments. ZY, JJ and YW performed the experiments and analyzed the data. ZY wrote this paper. All authors read and approved the final manuscript.

\section{Competing interests}

The authors declare that they have no competing interests.

\section{Consent for publication}

Not applicable.

\section{Ethics approval and consent to participate}

Healthy subjects were recruited in our study. Each participant provided written informed consent. The study protocol was approved by the Institutional Review Board of the Fourth Affiliated Hospital of Nanchang University, China.

\section{Publisher's Note}

Springer Nature remains neutral with regard to jurisdictional claims in published maps and institutional affiliations.

\section{Author details}

${ }^{1}$ The Fourth Affiliated Hospital of Nanchang University, Nanchang 330003 , China. ${ }^{2}$ People's Hospital of Shangrao City, Shangrao 334000, China. ${ }^{3}$ The Institute of Cardiovascular Sciences and Institute of Systems Biomedicine, School of Basic Medical Sciences, and Key Laboratory of Molecular Cardiovascular Sciences of Ministry of Education, Peking University Health Science Center, Beijing 100191, China.

Received: 22 February 2017 Accepted: 10 May 2017

Published online: 18 May 2017

\section{Reference}

1. Bates SR, Tao JQ, Yu KJ, Borok Z, Crandall ED, Collins HL, Rothblat GH. Expression and biological activity of ABCA1 in alveolar epithelial cells. Am J Respir Cell Mol Biol. 2008;38:283-92.
2. Navab M, Reddy ST, Van Lenten BJ, Fogelman AM. HDL and cardiovascular disease: atherogenic and atheroprotective mechanisms. Nat Rev Cardiol. 2011;8:222-32.

3. Barter PJ, Nicholls S, Rye KA, Anantharamaiah GM, Navab M, Fogelman AM. Antiinflammatory properties of HDL. Circ Res. 2004;95:764-72.

4. Gordon EM, Figueroa DM, Barochia AV, Yao X, Levine SJ. High-density Lipoproteins and Apolipoprotein A-I: Potential New Players in the Prevention and Treatment of Lung Disease. Front Pharmacol. 2016;7:323.

5. Levine DM, Parker TS, Donnelly TM, Walsh A, Rubin AL. In vivo protection against endotoxin by plasma high density lipoprotein. Proc Natl Acad Sci U S A. 1993;90:12040-4

6. Cockerill GW, Rye KA, Gamble JR, Vadas MA, Barter PJ. High-density lipoproteins inhibit cytokine-induced expression of endothelial cell adhesion molecules. Arterioscler Thromb Vasc Biol. 1995;15:1987-94.

7. Kolleck I, Schlame M, Fechner H, Looman AC, Wissel H, Rustow B. HDL is the major source of vitamin E for type II pneumocytes. Free Radic Biol Med. 1999;27:882-90.

8. Gonzalez RF, Dobbs LG. Isolation and culture of alveolar epithelial Type I and Type II cells from rat lungs. Methods Mol Biol. 2013;945:145-59.

9. Chung BH, Wilkinson T, Geer JC, Segrest JP. Preparative and quantitative isolation of plasma lipoproteins: rapid, single discontinuous density gradient ultracentrifugation in a vertical rotor. J Lipid Res. 1980;21:284-91.

10. Xu W, Xu L, Chen M, Mao YT, Xie ZG, Wu SL, Dong QR. The effects of low dose $X$-irradiation on osteoblastic MC3T3-E1 cells in vitro. BMC Musculoskelet Disord. 2012;13:94.

11. Pan B, Ren H, Ma Y, Liu D, Yu B, Ji L, Pan L, Li J, Yang L, Lv X, et al. Highdensity lipoprotein of patients with type 2 diabetes mellitus elevates the capability of promoting migration and invasion of breast cancer cells. Int J Cancer. 2012;131:70-82.

12. Pan B, Ren H, He Y, Lv X, Ma Y, Li J, Huang L, Yu B, Kong J, Niu C, et al. HDL of patients with type 2 diabetes mellitus elevates the capability of promoting breast cancer metastasis. Clin Cancer Res. 2012;18:1246-56.

13. Argraves KM, Gazzolo PJ, Groh EM, Wilkerson BA, Matsuura BS, Twal WO, Hammad SM, Argraves WS. High density lipoprotein-associated sphingosine 1-phosphate promotes endothelial barrier function. J Biol Chem. 2008;283:25074-81.

14. Kimura T, Tomura H, Sato K, Ito M, Matsuoka I, Im DS, Kuwabara A, Mogi C, Itoh $\mathrm{H}$, Kurose $\mathrm{H}$, et al. Mechanism and role of high density lipoproteininduced activation of AMP-activated protein kinase in endothelial cells. J Biol Chem. 2010:285:4387-97.

15. Sharifov OF, Xu X, Gaggar A, Grizzle WE, Mishra VK, Honavar J, Litovsky SH, Palgunachari MN, White CR, Anantharamaiah GM, Gupta H. Antiinflammatory mechanisms of apolipoprotein A-I mimetic peptide in acute respiratory distress syndrome secondary to sepsis. PLoS One. 2013;8:e64486.

16. Wurfel MM, Kunitake ST, Lichenstein H, Kane JP, Wright SD. Lipopolysaccharide (LPS)-binding protein is carried on lipoproteins and acts as a cofactor in the neutralization of LPS. J Exp Med. 1994;180:1025-35.

17. Wang L, Taneja R, Wang W, Yao L, Veldhuizen RA, Gill SE, Fortin D, Inculet R, Malthaner R, Mehta S. Human alveolar epithelial cells attenuate pulmonary microvascular endothelial cell permeability under septic conditions. PLoS One. 2013:8:e55311.

18. Chuquimia OD, Petursdottir DH, Periolo N, Fernandez C. Alveolar epithelial cells are critical in protection of the respiratory tract by secretion of factors able to modulate the activity of pulmonary macrophages and directly control bacterial growth. Infect Immun. 2013:81:381-9.

19. Park SW, Lee EH, Lee EJ, Kim HJ, Bae DJ, Han S, Kim D, Jang AS, Uh ST, Kim $\mathrm{YH}$, et al. Apolipoprotein A1 potentiates lipoxin A4 synthesis and recovery of allergen-induced disrupted tight junctions in the airway epithelium. Clin Exp Allergy. 2013;43:914-27.

20. Dai C, Yao X, Keeran KJ, Zywicke GJ, Qu X, Yu ZX, Dagur PK, McCoy JP, Remaley AT, Levine SJ. Apolipoprotein A-I attenuates ovalbumin-induced neutrophilic airway inflammation via a granulocyte colony-stimulating factor-dependent mechanism. Am J Respir Cell Mol Biol. 2012;47:186-95.

21. Dai C, Yao X, Vaisman B, Brenner T, Meyer KS, Gao M, Keeran KJ, Nugent GZ, Qu X, Yu ZX, et al. ATP-binding cassette transporter 1 attenuates ovalbumin-induced neutrophilic airway inflammation. Am J Respir Cell Mol Biol. 2014;51:626-36

22. McNeish J, Aiello RJ, Guyot D, Turi T, Gabel C, Aldinger C, Hoppe KL, Roach $\mathrm{ML}$, Royer $\mathrm{LJ}$, de Wet J, et al. High density lipoprotein deficiency and foam cell accumulation in mice with targeted disruption of ATP-binding cassette transporter-1. Proc Natl Acad Sci U S A. 2000;97:4245-50. 
23. Bates $\mathrm{SR}$, Tao JQ, Collins HL, Francone OL, Rothblat GH. Pulmonary abnormalities due to ABCA1 deficiency in mice. Am J Physiol Lung Cell Mol Physiol. 2005;289:L980-9.

24. Bortnick $\mathrm{AE}$, Favari $\mathrm{E}$, Tao JQ, Francone OL, Reilly M, Zhang $\mathrm{Y}$, Rothblat $\mathrm{GH}$, Bates SR. Identification and characterization of rodent ABCA1 in isolated type II pneumocytes. Am J Physiol Lung Cell Mol Physiol. 2003;285:L869-78.

25. Pan B, Ma Y, Ren H, He Y, Wang Y, Lv X, Liu D, Ji L, Yu B, Wang Y, et al. Diabetic HDL is dysfunctional in stimulating endothelial cell migration and proliferation due to down regulation of SR-BI expression. PLoS One. 2012;7:e48530.

26. Xiao GL, Luo ZQ, Xiao G, Li C, Xiong XD, Yang Y, Liu HJ. High-density lipoprotein attenuates lipopolysaccharide-induced acute lung injury in mice. Sheng Li Xue Bao. 2008;60:403-8.

27. Manicone AM. Role of the pulmonary epithelium and inflammatory signals in acute lung injury. Expert Rev Clin Immunol. 2009;5:63-75.

28. Thorley AJ, Ford PA, Giembycz MA, Goldstraw P, Young A, Tetley TD. Differential regulation of cytokine release and leukocyte migration by lipopolysaccharide-stimulated primary human lung alveolar type II epithelial cells and macrophages. J Immunol. 2007;178:463-73.

29. Witherden IR, Vanden Bon EJ, Goldstraw P, Ratcliffe C, Pastorino U, Tetley TD. Primary human alveolar type II epithelial cell chemokine release: effects of cigarette smoke and neutrophil elastase. Am J Respir Cell Mol Biol. 2004;30:500-9.

30. Vij N, Mazur S, Zeitlin PL. CFTR is a negative regulator of NFkappaB mediated innate immune response. PLoS One. 2009;4:e4664.

\section{Submit your next manuscript to BioMed Central and we will help you at every step:}

- We accept pre-submission inquiries

- Our selector tool helps you to find the most relevant journal

- We provide round the clock customer support

- Convenient online submission

- Thorough peer review

- Inclusion in PubMed and all major indexing services

- Maximum visibility for your research

Submit your manuscript at www.biomedcentral.com/submit 